(C) NIAB 2019. This is an Open Access article, distributed Plant Genetic Resources: Characterization and Utilization (2019) 17(2); 196-207 under the terms of the Creative Commons Attribution licence (http://creativecommons.org/licenses/by/ 4.0/), which permits unrestricted reuse, distribution, and reproduction in any medium, provided the

\title{
A regional approach to Nordic crop wild relative in situ conservation planning
}

\author{
Heli Fitzgerald ${ }^{1 *}$, Anna Palmé ${ }^{2}$, Åsmund Asdal ${ }^{2}$, Dag Endresen ${ }^{3}$, Elina Kiviharju ${ }^{4}$, \\ Birgitte Lund ${ }^{5}$, Morten Rasmussen ${ }^{6}$, Hjörtur Thorbjörnsson ${ }^{7}$ and Jens Weibull ${ }^{8}$ \\ ${ }^{1}$ Finnish Museum of Natural History, University of Helsinki, Helsinki, Finland, ${ }^{2}$ Nordic Genetic Resource \\ Centre (NordGen), Alnarp, Sweden, ${ }^{3} \mathrm{UiO}$ Natural History Museum in Oslo, University of Oslo, Oslo, \\ Norway, ${ }^{4}$ Natural Resources Institute Finland, Jokioinen, Finland, ${ }^{5}$ Agricultural Agency, Copenhagen, \\ Denmark, ${ }^{6}$ Norwegian Genetic Resource Center, Norwegian Institute of Bio-economy Research, As, \\ Norway, ${ }^{7}$ Reykjavík Botanic Garden, Reykjavík, Iceland and ${ }^{8}$ Board of Agriculture, Alnarp, Sweden
}

Received 19 November 2018; Accepted 30 November 2018 - First published online 6 February 2019

\begin{abstract}
Crop wild relatives (CWR) can provide one solution to future challenges on food security, sustainable agriculture and adaptation to climate change. Diversity found in CWR can be essential for adapting crops to these new demands. Since the need to improve in situ conservation of CWR has been recognized by the Convention on Biological Diversity (CBD) (2010) and the Global Strategy for Plant Conservation (2011-2020), it is important to develop ways to safeguard these important genetic resources. The Nordic flora includes many species related to food, forage and other crop groups, but little has been done to systematically secure these important wild resources. A Nordic regional approach to CWR conservation planning provided opportunities to network, find synergies, share knowledge, plan the conservation and give policy inputs on a regional level. A comprehensive CWR checklist for the Nordic region was generated and then prioritized by socio-economic value and utilization potential. Nordic CWR checklist was formed of 2553 taxa related to crop plants. Out of these, 114 taxa including 83 species were prioritized representing vegetable, cereal, fruit, berry, nut and forage crop groups. The in situ conservation planning of the priority CWR included ecogeographic and complementarity analyses to identify a potential network of genetic reserve sites in the region. Altogether 971,633 occurrence records of the priority species were analysed. A minimum number of sites within and outside existing conservation areas were identified that had the potential to support a maximum number of target species of maximum intraspecific diversity.
\end{abstract}

Keywords: crop wild relatives, food security, sustainable agriculture

\section{Introduction}

Climate change does not only threaten species, but also world food security (Rosenzweig and Parry, 1994). Major crops are already becoming severely affected by climate change-induced events such as droughts, floods, new pests and diseases (Kang et al., 2009; FAO, 2016) and having considerable impacts on agricultural production (IPCC, 2014). The arctic, boreal and alpine regions, which cover most of

*Corresponding author. E-mail: heli.fitzgerald@helsinki.fi the Nordic land area, are particularly vulnerable to effects of climate change on biodiversity and agriculture and the spread of pests and pathogens northwards (IPCC, 2007; Lindner et al., 2010; Bebber et al., 2013; Juhola et al., 2017).

Part of the solution to these challenges is provided by wild species related to crops, which harbour useful traits for food and forage crop improvement (Maxted and Kell, 2009; Helgadóttir et al., 2016; Dempewolf et al., 2017). However, many crop wild relatives (CWR) themselves are threatened and under-represented in species conservation programmes as their potential importance is not known or recognized (Ford-Lloyd et al., 2011), and are themselves susceptible to 
climate change (Jarvis et al., 2008a). The importance to conserve Plant Genetic Resources for Food and Agriculture (PGRFA) and their CWR has been recognized in many international treaties such as the $\mathrm{CBD}$ Strategic Plan for Biodiversity 2011-2020 (CBD, 2010), the International Treaty on Plant Genetic Resources for Food and Agriculture (FAO, 2001) and the Global Plan of Action for Plant Genetic Resources for Food and Agriculture (FAO, 2011).

The Nordic region consists of five countries in Northern Europe: Denmark, Finland, Iceland, Norway and Sweden ${ }^{1}$. The region has relatively low species diversity with approximately 3580 vascular plant taxa (Dyntaxa, 2016). However, wild species of the region are likely to harbour unique traits due to the extreme climate conditions and remote location. Several species growing in the Nordic region are at the edge of their distribution range, with distinct subspecies occurring in the area. Peripheral populations such as these can be genetically distinct from central populations and may have traits allowing adaptation to environmental change, as Lesica and Allendorf (1995) suggest. The numerous isolated islands of the region may contain unique intraspecific diversity, as described by Whittaker and Fernandez-Palacios (2007) and Hargreaves et al. (2010).

The Nordic region has a long history of collaboration strengthened by the formation of the Nordic Council in 1952. One example of Nordic cooperation is the Nordic Genetic Resource Center (NordGen), which houses regional plant genetic resource collections. Although NordGen secures regional genetic resources ex situ, further efforts to secure regional CWR in situ are warranted. The aim of this study was to build on Nordic synergies to conserve wild species related to agricultural crops in situ. Regional conservation planning provides complementary and costefficient solutions for Nordic CWR conservation along with networking opportunities that benefit both regional and national activities. The rationale for taking a regional approach for CWR conservation has previously been discussed by Maxted (2003) and Kell et al. (2017). We present here the methods and results of regional CWR conservation planning which included preparation of a CWR checklist and priority lists, an in situ conservation analysis and suggestions for regional in situ conservation of CWR taxa.

\section{Methods}

\section{Regional CWR species checklist}

When planning the conservation of Nordic CWR diversity, we prepared a consolidated checklist of Nordic CWR taxa (Fitzgerald et al., 2017a) by matching crop genera with

1 Greenland, the Faroe Islands and Åland maintain certain autonomy in the region, but are not treated specifically in this article.
Nordic vascular plant genera. We applied a broad definition of CWR (Maxted et al., 2006), where all the species in the same genus as a crop are given CWR status. We matched the Nordic vascular plant genera with a global crop genera list because all countries are interdependent on the use and conservation of plant genetic resources and most countries are dependent on crops whose primary regions of diversity are elsewhere (Maxted and Kell, 2009; Khoury et al., 2013). The Nordic flora includes genetic resources of wild species related to crops used in other parts of the world and likewise many crops cultivated in Nordic countries have not originated from the area.

The Nordic vascular plant list was compiled from national sources, but follows common taxonomy from Dyntaxa (2016). The national sources were Dyntaxa (2016) for Sweden, Lid and Lid (2005) for Norway, Lampinen and Lahti (2016) for Finland, Atlas Florae Danica (Hartvig, 2015) for Denmark and the 'List of flowering plants and ferns on Island' (Kristinsson, 1998) for Iceland. The crop genera list came from several sources: lists of medicinal, ornamental and forestry crops (IPK, 2003), food crops (FAO, 2001, 2005; Groombridge and Jenkins, 2002; EU, 2016) and forage crops Feedipedia, 2016; NordGen, 2016). The lists were taxonomically harmonized. The Nordic CWR checklist was reduced by removing hybrid and temporary species as well as those recently introduced species present in the Nordic region for $<10$ generations. Taxonomic experts were consulted to determine whether the species were established $<10$ generations. The indigenous, naturalized and temporary species status was found from the national and regional floras. Taxa considered indigenous or naturalized in at least one of the five countries were included.

\section{Prioritization among CWR}

The Nordic regional CWR checklist was subsequently prioritized by selecting wild relatives of food and forage crops with the greatest use potential. Fig. 1 illustrates the prioritization steps. Widely used prioritization criteria such as 'socio-economic value of crops' and 'potential value of wild relatives for variety improvement' (Kell et al., 2017) formed the basis for prioritization. First, wild species related to ornamental, forestry and medicinal crops were removed from the analysis, and species related to food and forage crops were selected for the prioritization process. The wild species related to food and forage crops were selected due to their role in food security as a source of traits when developing new varieties and adapting crop species to changing conditions such as climate change or new pests and diseases (Maxted and Kell, 2009; Dempewolf et al., 2017).

The second prioritization step was carried out separately for food and forage wild relative groups. The food wild 


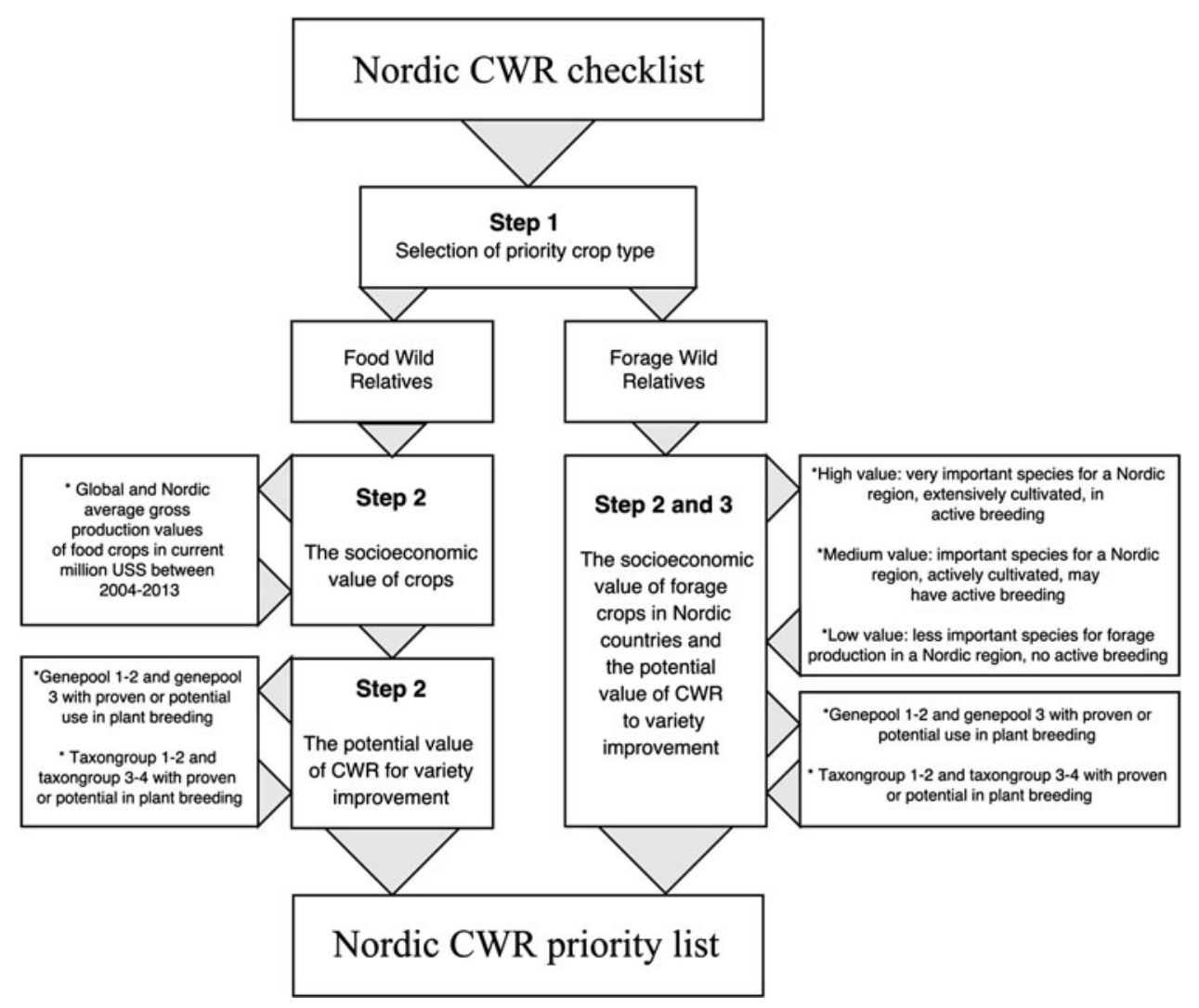

Fig. 1. Nordic region crop wild relative prioritization process.

relatives were prioritized based on global monetary values derived from FAO production values (FAO, 2015) for an average 10-year period. Both global and Nordic regional average gross production values in million US\$ for the years 2004-2013 were calculated and applied to all wild species related to the food crop genera. Those crop genera having an average global gross production value more than US\$200 million, were selected.

Data for the prioritization of the forage crops were collected in consultation with experts. A questionnaire was sent to breeders and other experts from each country, setting a priority for each forage genus in relation to importance and value in breeding and the scale of cultivation at a national level. National priority was estimated by breeders/experts for each Nordic country according to the following procedure. Top priority (Group 1) was given to genera with forage species that are commercially very important, are subject to active breeding in that country and are extensively cultivated. High priority (Group 2) was given to genera with forage species that are important, may be subject to active breeding in that country and are actively cultivated, but not included in Group 1 . Low priority (Group 3) was given to genera with forage species which are considered less important for forage production and where there is no active breeding. A regional priority level was calculated from the countries' responses and those species having the highest average across Nordic countries were selected.

The third part of the prioritization included applying the gene pool (GP) (Harlan and de Wet, 1971) and taxon group (TG) (Maxted et al., 2006) concepts. GP and TG group data were obtained from the Harlan and de Wet Crop Wild Relative inventory (Vincent et al., 2013; Crop Trust, 2016) and GRIN Global Taxonomy, World Economic Plants Database (USDA, 2016). Those wild species belonging to the primary (GP1b) and secondary (GP2) GPs of the crop and those in primary (TG1b) and secondary (TG2) TGs were prioritized. The taxa of the tertiary GP (GP3) or tertiary TG (TG 3 and 4) with proven use or potential use in plant breeding were also prioritized.

\section{Complementarity conservation analysis}

The aim of the in situ conservation analysis was to find potential genetic reserve sites (Maxted et al., 1997) for in situ conservation of priority CWR species in the Nordic countries. We used a method that combined a complementarity analysis, described by Rebelo (1994), with an ecogeographic land characterization (ELC) map of the region 
Table 1. Environmental variables used for creating ELC map for the Nordic priority CWR

\begin{tabular}{lllll}
\hline Code & Description & Unit & Source & Type \\
\hline Bio_1 & Annual average temperature & ${ }^{\circ} \mathrm{C}$ & Worldclim & Bioclimatic \\
Bio_12 & Annual rainfall & $\mathrm{mm}$ & Worldclim & Bioclimatic \\
Ref_depth & Depth of the soil unit & $\mathrm{M}$ & HWS database & Edaphic \\
T_oc & Organic carbon content in surface soil & $\%$ weight & HWS database & Edaphic \\
T_ph_h2o & pH in soil water solution in surface soil & $\log (\mathrm{H}+)$ & HWS database & Edaphic \\
Altitude & Elevation above sea level & $\mathrm{m}$ & Worldclim & Geophysical \\
Slope & Slope of the land surface & $\circ$ & SRTM DEM & Geophysical \\
Northness & Values close to 1 if facing northwards, -1 if facing southwards & & SRTM DEM & Geophysical \\
Eastness & Values close to 1 if facing eastwards, -1 if facing westwards & & SRTM DEM & Geophysical \\
\hline
\end{tabular}

(Parra-Quijano et al., 2012). The complementarity analysis is used to identify the minimum number of sites where a maximum number of target species occur (Maxted et al., 2008).

An ELC map is produced by multivariate analysis and delineates areas with similar environmental characteristics. ELC maps can therefore be used for various purposes in agrobiodiversity conservation to provide information on ecogeographic scenarios to assess plant adaptation in relation to the prevailing environmental conditions (Parra-Quijano, 2012). The idea behind combining the complementarity conservation analysis and the ELC map is that by conserving sites that reflect the ecogeographic variation of a species geographic distribution, we are conserving a broad range of genetic diversity that has adaptive importance. This potentially conserves the variation of genes of most interest for crop improvement (Maxted et al., 2013). As a part of the ecogeographic analysis, multispecies taxon richness and sampling bias maps were also created to provide additional information on the distribution data used. The maps were created using distribution data of priority species on DIVA-GIS (Hijmans et al., 2012), with a cell size of 0.1 degrees.

Relevant climatic, ecological and geographical data influencing target species adaptation were selected. Altogether nine variables from edaphic (HWS Database, 2012), geophysical (Reuter et al., 2007; Jarvis et al., 2008b) and bioclimatic (Hijmans et al., 2005; Worldclim, 2016; Fick and Hijmans, 2017) categories were selected to represent the target species adaptation (Table 1). The selection was based on variable selection used in the Norwegian diversity analysis (Phillips et al., 2016) and modified by national experts' advice to suit the entire Nordic region. The selected variables included average annual rainfall, average annual temperature, soil depth, organic carbon content in surface soil, $\mathrm{pH}$ in soil water solution of surface soil, elevation (asl.), slope and aspects (North and East). The ELC map was created using the Capfitogen ELC map tool (ParraQuijano, 2016). The parameters selected included latitude, elbow method, 5 arc-minute and four clusters allowed by each bioclimatic, edaphic and geophysical component, following the description in Parra-Quijano et al. (2014). For those cells where an ELC category was not assigned due to lack of variable data, the ELC category was assigned by extracting values from the nearest cell. This was done with a maximum distance of $15 \mathrm{~km}$ to the border of the nearest cell.

Several tools were used in the complementary conservation analysis for analysing data and displaying results: Capfitogen tools (Parra-Quijano, 2016), DIVA (Hijmans et al., 2012) and ArcGIS (ESRI, 2015). Target species distribution data were obtained from the Global Biodiversity Information Facility (GBIF), and national sources. These included GBIF (2016a) for Norway, GBIF (2016b) for Sweden, Lampinen and Lahti (2016) for Finland, GBIF (2016c) for Denmark and GBIF (2016d) and the database of the Icelandic Institute of Natural History (2016) for Iceland. The occurrence data were filtered by removing duplicate records, setting the georeferenced quality to a maximum of $1 \mathrm{~km}$ and checking for outlier locations. For each species occurrence point, only the most recent observation record was selected. Observations dated before year 1990 were discarded if the species had not been observed in that location since. The occurrence data types included observation, herbarium and gene bank data. Analysis was made on a species level. Altogether 971,633 occurrence records of priority species from the five Nordic countries were standardized into the Capfitogen format (Parra-Quijano, 2016), based on FAO/Bioversity Multi-Crop Passport Descriptors (Alercia et al., 2012).

The Finnish plant distribution records were available on a $1 \mathrm{~km}^{2}$ grid system instead of a coordinate format. Therefore, centroids of the grid squares had to be calculated and transferred into coordinate points. If the grid square was only partly inside the country boundary and the species distribution point was near the edge of the boundary, the observation points were inadvertently not included in the analysis. This was a particular problem on 
the Southern coastline and archipelago species-rich areas. The solution was to assign new coordinates to the closest land point.

For the ecogeographic complementary analysis, the Capfitogen Complementary tool (Parra-Quijano, 2016) was used with the ELC map to find potential genetic reserve locations. Two separate analyses were performed. First, a grid cell complementarity analysis for the whole land area of the Nordic countries was performed on a resolution of 5 arc-minutes (approximately $10 \mathrm{~km}$ grids). Second, a protected area (PA) complementarity analysis was carried out by selecting sites within PAs, using the data from World Database of Protected Areas (UNEP-WCMC and IUCN, 2016) on resolution of 30 arc-seconds $\left(1 \mathrm{~km}^{2}\right)$. All types of PAs were included in the analysis (i.e. National Parks, National Reserves and protected landscapes).

\section{Results}

\section{CWR inventory and prioritization}

A regional CWR checklist for the Nordic countries was created including 2553 CWR taxa (Fitzgerald et al., 2017a), which is about $70 \%$ of the total Nordic vascular plant flora. The final checklist consists of native, archaeophyte and established neophyte vascular plant species occurring in the Nordic region. According to Kalliola (1973), the species introduced to the Nordic region before 17 th century are considered archaeophytes and afterwards neophytes. Approximately one-third of the regional checklist taxa are related to food and forage crops only. However, the majority of CWR taxa are related to multiple crop types, for example, apple (Malus) and cherry (Prunus) species which are related to medicinal, food, forestry and ornamental crop categories.

Altogether the Nordic CWR priority list includes 114 taxa (online Supporting information 1). These include 83 species from 35 genera representing wild relatives of eight crop groups: vegetables, cereals, fruits, berries, nuts, and grass and legume forages. The vegetable group includes species related to Brassica, onion, lettuce, carrot and field/broad bean. The cereals include wild relatives of oat and millet. The fruit group includes wild relatives of fruit trees such as apple, pear, cherry, apricot, almond and plum. Wild relatives of cultivated berries are one of the largest groups, and include strawberry, raspberry, blackberry, blueberry, lingonberry, cloudberry, black currant and red currant. Nut relatives include wild hazelnut and walnut. The forage wild relatives can be divided into forage legumes and forage grasses and include species from many genera such as Trifolium, Poa, Festuca, Phleum, Lolium and Medicago. The priority taxa crop GP and TG concepts and the distribution classes in Nordic countries are listed in Fitzgerald et al. (2017b).

\section{Species richness and sample bias maps}

Multi-species taxon richness and sampling bias maps were created for the 83 priority species. The species richness map (online Supporting information 3) shows a pattern of higher richness in the southern parts of the region and lower richness in the northern parts. Naturally species-poor areas include Vatnajökull glacier in Iceland and Jostedalsbreen glacier in Norway along with many larger lakes and mountainous areas of the region. The sampling bias map (online Supporting information 4) shows fewer sampled areas in the Northern parts of Norway, Finland and Sweden, particularly in Finnmark County and highly sampled areas around larger cities such as Copenhagen, Helsinki, Oslo, Oulu and Stockholm.

\section{ELC maps}

The Nordic ELC map contains 26 ecogeographic categories (Fig. 2 and online Supporting information 2). These zones reflect potential adaptation of the priority species in the Nordic region based on bioclimatic, geophysical and edaphic characteristics. The ELC map was used in Capfitogen's Complementary tool to find complementary in situ conservation areas that potentially reflect the intraspecific variation of the priority CWR based on the genetic adaptation to different environments.

\section{Complementarity conservation analysis}

Altogether 971,633 occurrence records of the 83 priority species were analysed in Capfitogen's Complementary tool to find potential genetic reserve locations complementing each other. The results of the grid cell analysis show a network of 299 grid cells (Fig. 3 and online Supporting information 5) needed to conserve all the taxon-ELC zone combinations in at least one location. By using the ELC zones, the within-species diversity is taken into account in the conservation planning. The first complementary cell is closely located to Oslo in Drammen, Norway, and contained 116 priority taxa-ELC combinations. The second cell, in Oulu, Finland, had 64 complementary taxa-ELC combinations which were not found in the first site. The third cell near Kristiansand, Norway, had 61 and the fourth cell is on the border of Helsinki and Espoo cities, while Finland had 55 priority taxa-ELC combinations.

The results of the PA complementary analysis showed a network of 162 complementary genetic reserves within existing conservation areas (Fig. 4 and online Supporting information 6 and 7) with altogether 8164 observations of the target species. The first complementary PA site, covering the highest number of target species per ELC zone, was in Aalborg Kommune, Denmark. It contained 88 target species in two ELC zones. Each species is counted separately in 


\section{Nordic ELC categories for priority CWR species}
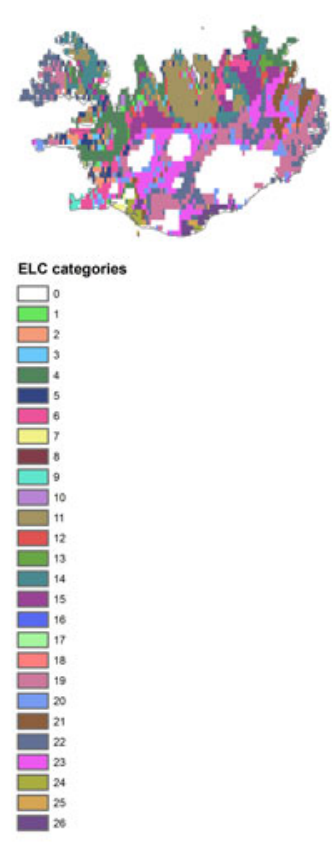

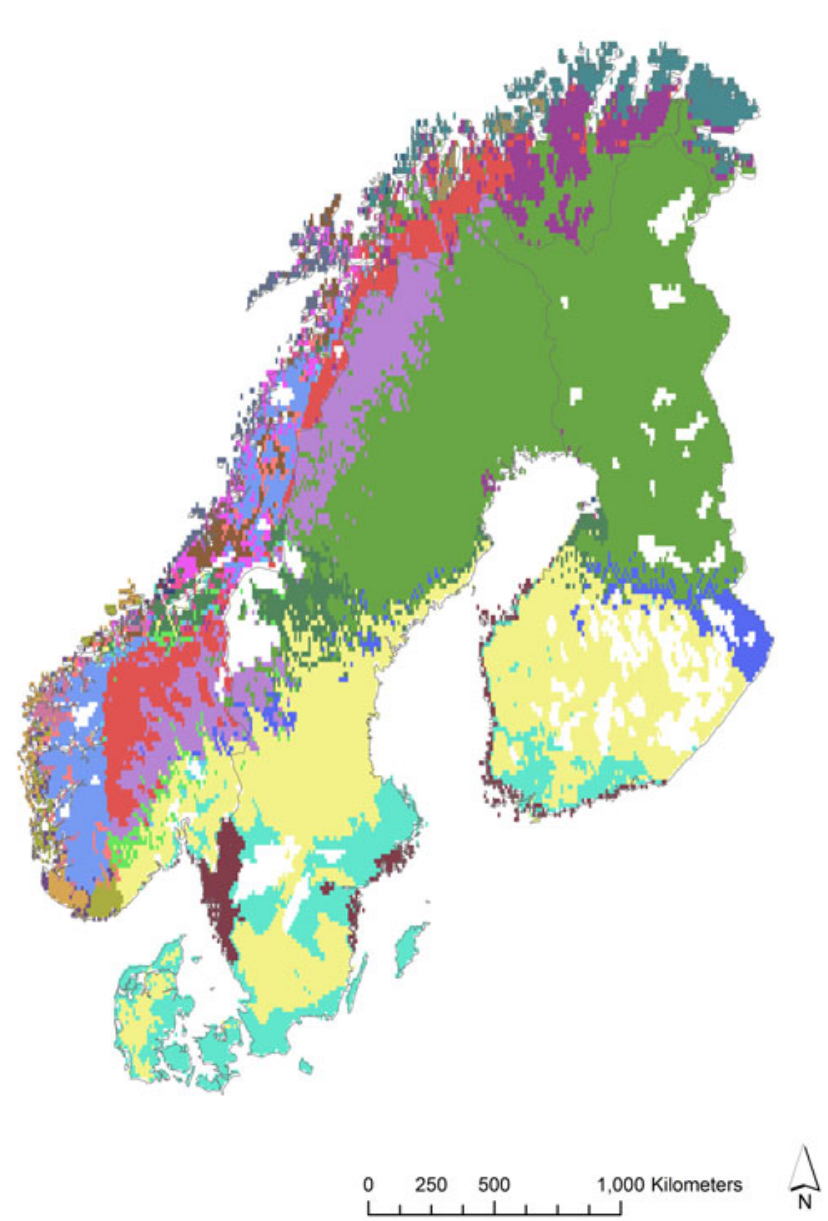

Fig. 2. The Nordic region ecogeographic land characterization (ELC) map with 26 ELC categories. The ELC categories represent different environments based on bioclimatic, geophysical and edaphic characteristics. Ecogeographic diversity is used as a proxy for genetic diversity of the priority CWR species in the complementarity conservation analysis. The ELC data analysis was undertaken with Capfitogen ELC map tool, DIVA (Hijmans et al., 2012) and ArcGIS 10.3.1. (ESRI, 2015).

different ELC zones, representing the unique ecogeographic diversity of the species in that zone. The second site was the area of the Tornio and Muonio rivers in Northern Finland, a large natural-state river system bordering Sweden. The PA had three ELC zones with 59 complementary target taxa not present in the first site. The third was the Lista Wetlands system, Norway with 46 complementary taxa in two ELC zones. The fourth site was in the Tammisaari and Hanko Archipelago and Pojo Bay marine protection area, Finland, and included three ELC zones containing 42 complementary taxa not present in previous sites. The total number of target taxa in the site was 86 .

The 83 target species have altogether 822 taxon-ELC zone combinations (online Supporting information 7). The number of target species observations varied from 1 to 25,779 , depending on the distribution of the species in the PAs and the ELC zones. The importance of ensuring that viable populations are conserved and maintained in genetic reserves is described by Iriondo et al. (2012). With a sufficient number of populations, a taxon is less likely to be destroyed when facing possible adverse effects in situ. If observations are counted as populations and a minimum number of target species populations in in situ conservation is set for five populations (Brown and Briggs, 1991; Dulloo et al., 2008), 554 out of 822 taxon-ELC zone populations in this study fulfil these criteria. When looking at numbers of species populations in all of the 26 ELC zones, there are only six species (Brassica nigra (L.) W. D. J. Koch, Lactuca quercina L., Lactuca tatarica (L.) C. A. Mey., Prunus mahaleb L., Rubus allegheniensis Porter ex L. H. Bailey, Rubus spectabilis Pursh) having fewer than five populations present in the complementary PAs.

\section{Discussion}

\section{Advantage of Nordic regional planning}

The results of the floristic analysis of the checklist showed that the same species were largely shared across 


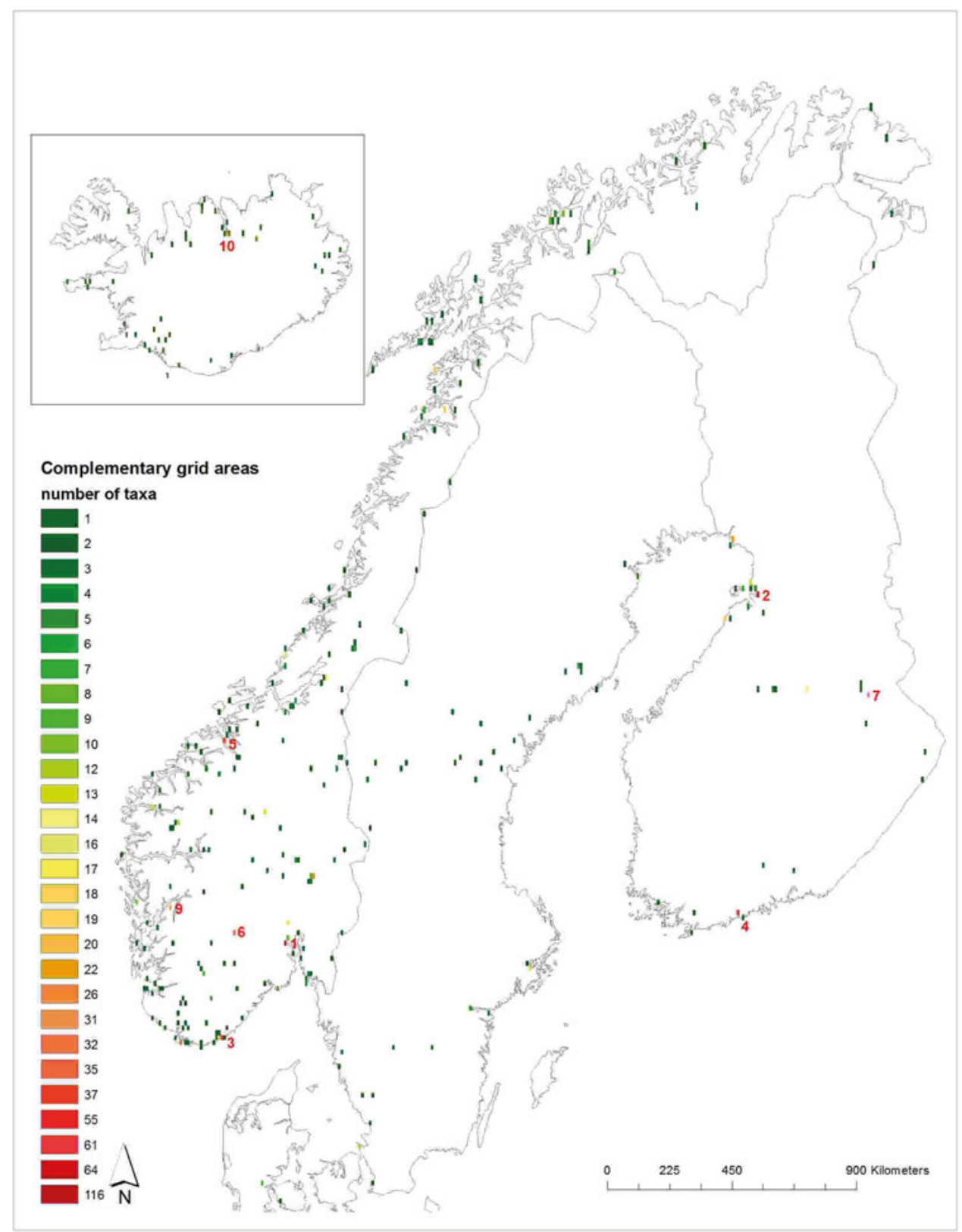

Fig. 3. The grid cell complementary network map for the Nordic priority CWR. This map shows the lowest number of geographical grids that can conserve the intraspecific diversity of the target taxa when the ecogeographic diversity is taken as a proxy for genetic diversity. The top 10 cells, containing the largest number of complementary taxa, are labelled. The colour represents the number of CWR priority taxa found in each grid. Detailed information of the sites and species numbers in each location can be found in Supporting information 6. The ELC data analysis was undertaken using Capfitogen ELC map tool, DIVA (Hijmans et al., 2012) and ArcGIS 10.3.1. (ESRI, 2015). The Nordic region boundary layers are from Natural Earth data (2016).

the Nordic countries and a majority of the prioritized CWR have a wide distribution in the Nordic region. Approximately $80 \%$ of the priority taxa are distributed in four or five of the Nordic countries. Similar climate zones and photoperiodic conditions are found across the Nordic countries and the breeding activities and interests are relatively similar. The existence of a working regional administrative body, the Nordic Council of Ministers, as well as a regional gene bank for ex situ conservation, NordGen, adds to the rationale for the Nordic regional approach for planning in situ conservation of CWR. However, the integration of national, regional and global CWR conservation strategies, as described by Maxted et al. (2015), is important. Ideally, these levels should 


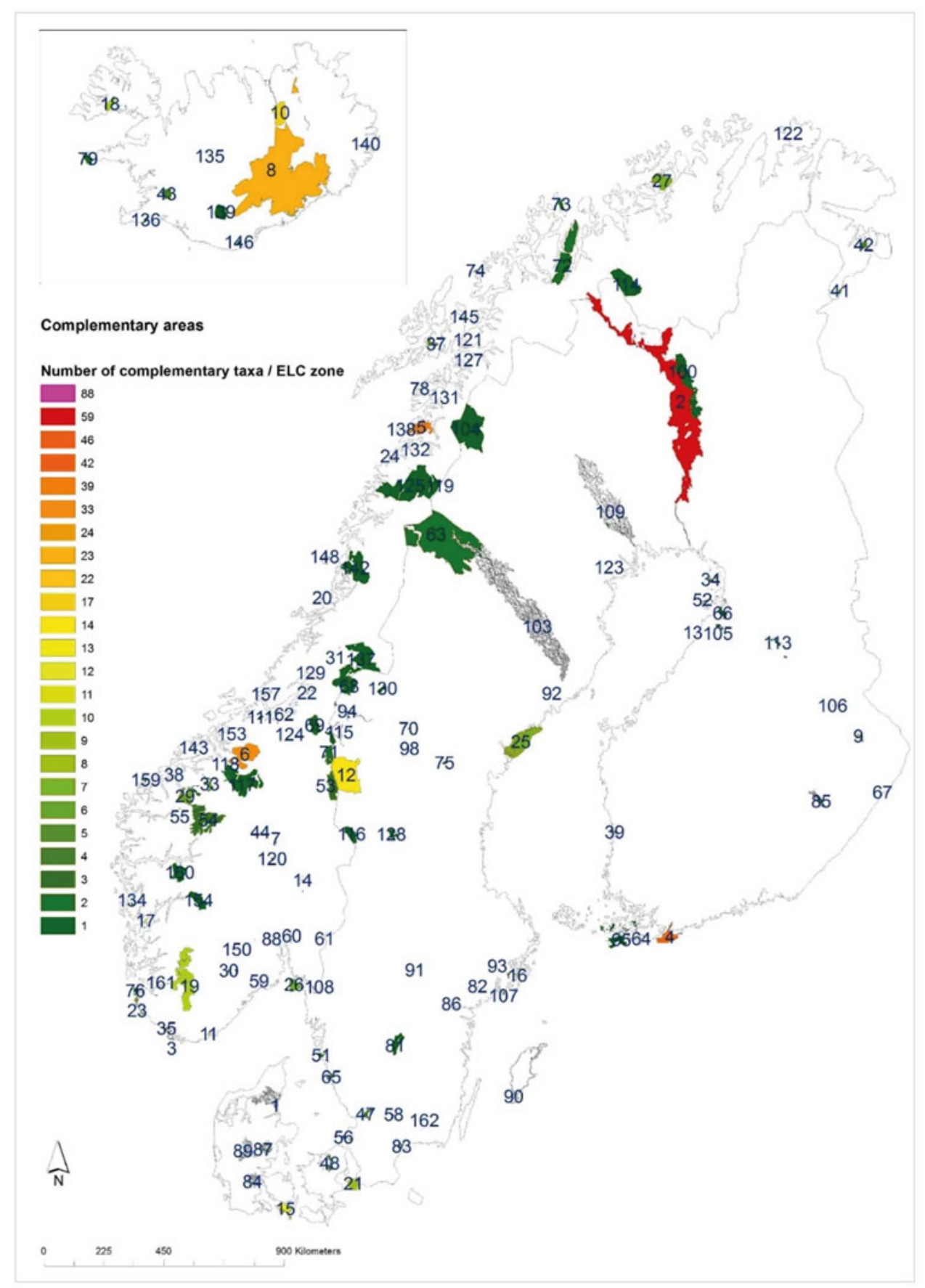

Fig. 4. The protected area complementary network map for the Nordic priority CWR. This map shows the protected areas where the intraspecific diversity of the target taxa could be conserved when the ecogeographic diversity is taken as a proxy for genetic diversity. The sites are marked in a complementary order, starting from the site which has highest number of species-ELC combinations. Detailed information on the sites and species numbers in each location can be found in Supporting information 6. The colours represent the number of complementary taxa per ELC zone (=ELC category as seen in Fig. 2). The ELC data analysis was undertaken with Capfitogen ELC map tool, DIVA (Hijmans et al., 2012) and ArcGIS 10.3.1. (ESRI, 2015). The Nordic region boundary layers are taken from Natural Earth data (2016).

complement and reinforce each other. Other conservation approaches have previously been successfully integrated into a multi-level system, such as the Natura 2000 network in Europe.

\section{Nordic species checklist and priority list}

The Nordic species checklist is an extensive list including all CWR species connected to food and fodder crops in 
the region (Fitzgerald et al., 2017a). It is publically available and can be used both for national planning in each of the Nordic countries and regional planning on the Nordic level as well as into larger scale regional (European) and global conservation planning and analysis.

Prioritizing among taxa on the checklist provided a more cost-effective way to plan in situ conservation on both national and regional levels. The most important CWR species of the region, regarding value and utilization potential, have been included in the priority list. We argue that the Nordic region has a collective responsibility to conserve the priority CWR growing in the region. These are, for example, the wild relatives of cultivated berries, forages and vegetable species.

\section{Identifying Nordic in situ conservation sites}

The results from the complementarity conservation analysis suggest how priority CWR could be conserved in situ. A complementarity approach in conservation planning and reserve selection is a widely used method in designing conservation area networks (Rebelo, 1994; Margules and Pressey, 2000; Kukkala and Moilanen, 2012). Genetic reserves are conservation areas set up with the specific purpose of long-term conservation of genetic diversity, and quality standards have been set up on how to best conserve CWR in genetic reserves (Iriondo et al., 2012). We took two approaches in planning the regional in situ genetic reserve network for Nordic countries: the grid cell complementary network and the PA complementary network. In both options, we used the ELC map of the region to identify not only complementary areas to conserve target CWR species, but to maximize ecogeographic diversity, to better capture and conserve potential intraspecific diversity based on presumed adaptation to diverse environments.

In the grid cell complementary analysis, many top cells (geographic areas having the highest CWR diversity) were situated near larger cities, a partial result of an observation bias. Overall, the cells were situated relatively evenly over the region. However, the number of cells in southern and western Norway exceeded the number of cells in other countries. Even the least observed area Finnmark, northern Norway, had several complementary cells. This can be attributed to the distribution pattern of ELC zones over the region and Norway having more ELC zones. This may be further explained by Norway demonstrating more variation in the selected climatic, ecological and geographical variables than other countries. Iceland had more ELC categories than either Denmark, Finland or Sweden. Iceland had a relatively large number of complementary cells considering that fewer target species occur in Iceland than in other countries. This was at least partly due to several unique ELC categories. Whereas the land areas of Sweden and Finland were more homogeneous, there was still a distinct division into several different ELC zones. Denmark, however, is covered by only one ELC zone. In conclusion, it is not possible to aim for even geographic distribution of complementary cells in the analysis as the bioclimatic conditions along with the observation level and distribution of species determine the locations of the cells. If the grid cell approach was to be developed further, a closer look at the urbanization and land use would show where the genetic reserves could be situated since many high diversity cells are located within, or in the vicinity of, larger cities.

The goal of the PA complementary network analysis was to identify sites for genetic reserves within existing PAs. The genetic reserve sites were located relatively evenly around the region. However, the southern and western parts of Norway and Sweden seemed to have a dense network of complementary sites. While the top sites had the highest number of complementary species, the entire network of sites is important because each ELC class represents a specific environment, thus valuable for capturing specific ecotypic variation. Some sites with fewer complementary species nevertheless had a large total number of species. Furthermore, the proposed sites were located within designated PAs. The PA network approach had the advantage that it identified CWR species in already established conservation sites and therefore no new conservation areas need to be established. However, if a PA is to be established as a genetic reserve, a more detailed study would need to be conducted to determine the most appropriate PAs to support such a reserve, validate and inventory CWR species within the PA, identify the most appropriate populations to conserve and establish management and monitoring plans for the populations according to available guidelines (such as Iriondo et al., 2012).

\section{Conservation recommendations}

In conclusion, based on the results of the analysis, we suggest the following conservation measures for Nordic CWR:

- Investigate how to continue to harmonize future regional and national conservation actions in the Nordic countries with an aim of implementing more efficient conservation actions;

- Increase efforts to collect distribution data of target species, especially in insufficiently sampled areas and for species which have fewer than five populations in the complementary PA network;

- Assess the suitability of the PAs found to be complementary sites for CWR species, for establishment of genetic reserves; 
- As a first step, establish one genetic reserve per Nordic country to gain experience, evaluate currently suggested management plans and policy constraints; and

- Ensure free and open access to CWR data sources for open validation and reuse of species occurrence data for other purposes through platforms such as the GBIF.

Currently, there is an ongoing process to produce a common Nordic report on conservation planning, including recommendations on future in situ as well as ex situ actions to safeguard the CWR genetic resources in the region. It will be available via the Nordic CWR homepage (http:// www.nordgen.org/cwr) where other CWR information and conservation planning tools can be found. A policy brief has been produced focusing on CWR and actions needed in the Nordic region to assure long-term conservation of CWR (http://www.nordgen.org/ngdoc/NordicCWR_2016/ Policy\%20brief.pdf).

\section{Supplementary material}

The supplementary material for this article can be found at https://doi.org/10.1017/S147926211800059X.

\section{Acknowledgements}

We would like to thank the Nordic Council of Ministers for providing funding; Mora Aronsson for providing taxonomic data and assistance; Raino Lampinen, Pawel Wasowicz and GBIF for providing species distribution data; Mauricio Parra-Quijano for technical assistance with Capfitogen tools and Jade Phillips for assistance in diversity analysis.

\section{References}

Alercia A, Diulgheroff S and Mackay M (2012) FAO/Bioversity Multi-Crop Passport Descriptors V.2 [MCPD V.2]. Rome, Italy: Food and Agriculture Organization of the United Nations (FAO); Rome, Italy: Bioversity International, 11 p. Available at http://www.bioversityinternational.org/fileadmin/user_ upload/online_library/publications/pdfs/FAO-Bioversity_ multi_crop_passport_descriptors_V_2_Final_rev_1526.pdf.

Bebber D, Ramotowski M and Gurr S (2013) Crop pests and pathogens move polewards in a warming world. Nature Climate Change 3: 985-988.

Brown AHD and Briggs JD (1991) Sampling strategies for genetic variation in ex situ collections of endangered plant species. In: Falk DA and Holsinger KE (eds) Genetic and Conservation of Rare Plants. New York: Oxford University Press, pp. 99-119.

CBD (2010) Strategic Plan for Biodiversity 2011-2020 and the Aichi Biodiversity Targets. United Nations, Montreal, Canada: Secretariat of the Convention on Biological Diversity: http:// cbd.int/sp (Accessed: 10/09/2017).

Crop Trust (2016) The Harlan and de Wet Crop Wild Relative Inventory. Germany: Global Crop Diversity Trust. https:// www.cwrdiversity.org/checklist/ (Accessed 31/02/2016).
Dempewolf H, Baute G, Anderson J, Kilian B, Smith C and Guarino L (2017) Past and future use of wild relatives in crop breeding. Crop Science 57: 1070-1082.

Dulloo ME, Labokas J, Iriondo JM, Maxted N, Lane A, Laguna E, Jarvis A and Kell SP (2008) Genetic reserve location and design. In: Iriondo JM, Maxted $\mathrm{N}$ and Dulloo ME (eds) Conserving Plant Genetic Diversity in Protected Areas. Wallingford: CABI Publishing, pp. 23-64.

Dyntaxa (2016) Swedish Taxonomic Database. http://www.dyn taxa.se (Accessed: 15/1/2016).

ESRI (2015) ArcGIS Desktop: Release 10.3.1. Redlands, CA: Environmental Systems Research Institute.

EU (2016) Plant Variety Catalogues, Databases \& Information Systems for Agricultural and Vegetable species. EU database of registered plant varieties, European commission. Available at https://ec.europa.eu/food/plant/plant_propagation_mater ial/plant_variety_catalogues_databases_en (Accessed 7/1/ 2016).

FAO (2001) International Treaty on Plant Genetic Resources for Food and Agriculture, Annex I Taxa. Food and Agriculture Organization of the United Nations. http://www.planttreaty. org/ (Accessed 10/9/2017).

FAO (2005) Alphabetical list of crops with botanical name and crop code. In: A System of Integrated Agricultural Censuses and Surveys, World Programme for the Census of Agriculture, Volume 1. Rome: FAO Statistical Development Series, FAO. http://www.fao.org/fileadmin/templates/ess/ documents/world_census_of_agriculture/appendix4_r7.pdf (Accessed 1/11/2016).

FAO (2011) Second Global Plan of Action for Plant Genetic Resources for Food and Agriculture. Commission on Genetic Resources for Food and Agriculture. Rome, Italy: Food and Agriculture Organisation of the United Nations, FAO. ISBN 978-92-5-107163-2. http://fao.org/docrep/015/ i2624e/i2624e00.pdf.

FAO (2015) FAOSTAT. Rome, Italy: Statistics Division, Food and Agriculture Organization of the United Nations. http://www. fao.org/faostat/en/\#home (Accessed 1/11/2015).

FAO (2016) The State of Food and Agriculture - Climate Change, Agriculture and Food Security. Food and Agriculture Organization of United Nations, FAO. ISBN 978-92-5-109374-0. Available at http://www.fao.org/3/a-i6030e.pdf.

Feedipedia (2016) Forage Genera List, Animal Feed Resources Information System. INRA CIRAD AFZ and FAO 2012-2015. http://www.feedipedia.org (Accessed 9/1/2016).

Fick SE and Hijmans RJ (2017) Worldclim 2: new 1-km spatial resolution climate surfaces for global land areas. International Journal of Climatology 37: 4302-4315.

Fitzgerald H, Aronsson M, Asdal Å, Endresen D, Kiviharju E, Lund B, Palmé A, Rasmussen M, Weibull J and Porbjörnsson H (2017a) Nordic Crop Wild Relative Checklist Dataset, Version 1.10. Nordic Genetic Resource Center, NordGen. Available at https://doi.org/10.15468/itkype.

Fitzgerald H, Aronsson M, Asdal A, Endresen D, Kiviharju E, Lund B, Palmé A, Lund B, Rasmussen $M$, Weibull $J$ and Porbjörnsson H (2017b). The Nordic priority crop wild relative gene pool and distribution dataset. Available at https:// doi.org/10.6084/m9.figshare.5688130.v1.

Ford-Lloyd BV, Schmidt M, Armstrong SJ, Barazani O, Engels J, Hadas R, Hammer K, Kell S, Kang D, Khoshbakht K, Li Y, Long C, Lu B, Ma K, Nguyen VT, Qiu L, Ge S, Wei W, Zhang $Z$ and Maxted N (2011) Crop wild relatives undervalued, underutilized and under threat? BioScience 61: $559-565$. 
GBIF (2016a) Norway occurrence data. GBIF.org (27th May 2016) GBIF Occurrence Download http://doi.org/10.15468/dl. heawlq.

GBIF (2016b) Sweden occurrence data. GBIF.org (27th May 2016) GBIF Occurrence Download http://doi.org/10.15468/dl. z7jfht.

GBIF (2016c) Denmark occurrence data. GBIF.org (27th May 2016) GBIF Occurrence Download http://doi.org/10.15468/ dl.i1smvp.

GBIF (2016d) Iceland occurrence data. GBIF.org (27th May 2016) GBIF Occurrence Download http://doi.org/10.15468/dl. awmou9.

Groombridge B and Jenkins MD (2002) Appendix 2: Important food crops. In: World Atlas of Biodiversity. Berkeley, USA: UNEP World Conservation Monitoring Centre, University of California Press, pp. 244-270.

Hargreaves S, Maxted N, Hirano RAbberton M, Skøt L and Ford-Lloyd B (2010) Islands as refugia of Trifolium repens genetic diversity. Conservation Genetics 11: 1317-1326.

Harlan J and de Wet J (1971) Towards a rational classification of cultivated plants. Taxon 20: 509-517.

Hartvig P ed. (2015) Atlas Flora Danica, volume 1-3. Dansk Botanisk Förening, Gyldendal, Denmark. p. 1565. http://atlas floradanica.dk/.

Helgadóttir Á, Østrem L, Collins RP, Humphreys M, Marshall A, Julier B, Gastal F, Barre P and Louarn G (2016) Breeding forages to cope with environmental challenges in the light of climate change and resource limitations. In: Roldán-Ruiz I, Baert J and Reheul D (eds) Breeding in a World of Scarcity. Cham: Springer, pp. 3-14. doi: 10.1007/ 978-3-319-28932-8_1.

Hijmans RJ, Cameron SE, Parra JL, Jones PG and Jarvis A (2005) Very high resolution interpolated climate surfaces for global land areas. International Journal of Climatology 25: 19651978.

Hijmans R, Guarino L and Mathur P (2012) DIVA-GIS. Version 7.5. A geographic information system for the analysis of species distribution data. http://www.diva-gis.org (Accessed October 2016).

HWS Database (2012) Harmonized World Soil Database, Version 1.2. Rome, Italy: IIASA; Luxemburg, Austria: FAO/IIASA/ISRIC/ ISSCAS/JRC. FAO. http://webarchive.iiasa.ac.at/Research/LUC/ External-World-soil-database/HTML/ (Accessed 10/09/2016).

Icelandic Institute of Natural History (2016) Database of the Icelandic Institute of Natural History. http://en.ni.is/botany/.

IPCC (2007) Especially affected systems, sectors and regions. In: Climate Change 2007: Synthesis Report. A Contribution of Working Groups I, II, and III to the Fourth Assessment Report of the Intergovernmental Panel on Climate Change (IPCC). Geneva, Switzerland: IPCC.

IPCC (2014) Summary for policymakers. In: Field CB, Barros VR, Dokken DJ, Mach KJ, Mastrandrea MD, Bilir TE, Chatterjee M, Ebi KL, Estrada YO, Genova RC, Girma B, Kissel ES, Levy AN, MacCracken S, Mastrandrea PR and White LL (eds) Climate Change 2014: Impacts, Adaptation, and Vulnerability. Part A: Global and Sectoral Aspects. Contribution of Working Group II to the Fifth Assessment Report of the Intergovernmental Panel on Climate Change. Cambridge, UK and New York, NY, USA: Cambridge University, pp. 1-32.

IPK (2003) Mansfeld's World Database of Agricultural and Horticultural Crops. Leibniz Institute of Plant Genetics and Crop Plant Research. Available from http://mansfeld.ipk-ga tersleben.de/apex/f?p=185:3:0.
Iriondo JM, Maxted N, Kell SP, Ford-Lloyd BV, Lara-Romero C, Labokas J and Magos Brehm J (2012) Identifying quality standards for genetic reserve conservation of CWR. In: Maxted N, Dulloo ME, Ford-Lloyd BV, Frese L, Iriondo JM and Pinheiro de Carvalho MAA (eds) Agrobiodiversity Conservation: Securing the Diversity of Crop Wild Relatives and Landraces. Wallingford, UK: CAB International, pp. 72-77.

Jarvis A, Lane A and Hijmans R (2008a) The effect of climate change on crop wild relatives. Agriculture, Ecosystems $\varepsilon$ Environment 126: 13-23.

Jarvis A, Reuter HI, Nelson A and Guevara E (2008b) Hole-filled SRTM for the globe. Version 4, Available from the CGIAR-CSI SRTM 90 m Database. http://srtm.csi.cgiar.org (Accessed 10/ 9/2016).

Juhola S, Kleinc N, Käyhkö J and Schmid Neset T (2017) Climate change transformations in Nordic agriculture? Journal of Rural Studies 51: 28-36.

Kalliola R (1973) Suomen kasvimaantiede. Helsinki: WSOY, 308 p.

Kang Y, Khan S and Ma X (2009) Climate change impacts on crop yield, crop water productivity and food security - a review. Progress in Natural Science 19: 1665-1674.

Kristinsson HG (1998) Flowering Plants and Ferns of Iceland. Iceland: Mal og Menning.

Kell SP, Ford-Lloyd BV, Magos Brehm J, Iriondo JM and Maxted N (2017). Broadening the base, narrowing the task: prioritizing crop wild relative taxa for conservation action. Crop Science 57: 1042-1058.

Khoury CK, Achicanoy HA, Bjorkman AD, Navarro-Racines C, Guarino L, Flores-Palacios X, Engels J, Wiersema J, Dempewolf $\mathrm{H}$, Ramírez-Villegas J, Castañeda-Álvarez N, Fowler C, Jarvis A, Rieseberg L and Struik P (2013) Estimation of Countries' Interdependence in Plant Genetic Resources Provisioning National Food Supplies and Production Systems. The International Treaty on Plant Genetic Resources for Food and Agriculture, FAO, Research Study 8. 26 p. http:// www.fao.org/3/a-bq533e.pdf

Kukkala AS and Moilanen A (2012) Core concepts of spatial prioritisation in systematic conservation planning. Biological Reviews 88: 443-464.

Lampinen R and Lahti T (2016) Kasviatlas. Helsinki, Finland: Helsinki University, Finnish Natural History Museum. http:// koivu.luomus.fi/kasviatlas. (Accessed 07/09/2016).

Lid J and Lid DT (2005) Norsk flora, 7th edn. Oslo: Det Norske Samlaget.

Lesica P and Allendorf FW (1995) When are peripheral populations valuable for conservation? Conservation Biology 9: 753-760.

Lindner M, Maroschek M, Netherer S, Kremer A, Barbati A, Garcia-Gonzalo J, Seidl R, Delzon S, Corona P, Kolström M, Lexer MJ and Marchetti M (2010) Climate change impacts, adaptive capacity, and vulnerability of European forest ecosystems. Forest Ecology and Management 259: 698-709.

Margules CR and Pressey RL (2000) Systematic conservation planning. Nature 405: 243-253.

Maxted N (2003) Conserving the genetic resources of crop wild relatives in European Protected Areas. Biological Conservation 113: 411-417.

Maxted N and Kell SP (2009) Establishment of A Global Network for the in Situ Conservation of Crop Wild Relatives: Status and Needs. Rome: Commission on Genetic Resources for Food and Agriculture, FAO. http://www.fao.org/docrep/ 013/i1500e/i1500e18d.pdf. 
Maxted N, Hawkes JG, Hawkes JG and Williams JT (1997) A practical model for in situ genetic conservation. In: Maxted N, Ford-Lloyd BV and Hawkes JG (eds) Plant Genetic Conservation; the in situ Approach. London: Chapman and Hall, pp. 339-367.

Maxted N, Ford-Lloyd BV, Jury S, Kell S and Scholten M (2006) Towards a definition of a crop wild relative. Biodiversity and Conservation 15: 2673-2685.

Maxted N, Dulloo E, Ford-Lloyd B, Iriondo J and Jarvis A (2008) Gap analysis: a tool for complementary genetic conservation assessment. Diversity and Distributions 14: 1018-1030.

Maxted N, Magos Brehm J. and Kell SP (2013) Resource Book for Preparation of National Conservation Plans for Crop Wild Relatives and Landraces. FAO Commission on Genetic Resources for Food and Agriculture. http://www.fao.org/filead min/templates/agphome/documents/PGR/PubPGR/Resource Book/TEXT_ALL_2511.pdf

Maxted N, Avagyan A, Frese L, Iriondo JM, Magos Brehm J, Singer A and Kell SP (2015) Concept for in Situ Conservation of Crop Wild Relatives of Crop Wild Relatives in Europe. Wild species conservation in genetic reserves working group, European Cooperative Program for Plant Genetic Resources. http://www.ecpgr.cgiar.org/fileadmin/templates/ecpgr.org/ upload/WG_UPLOADS_PHASE_IX/WILD_SPECIES/Concept_ for_in_situ_conservation_of_CWR_in_Europe.pdf.

Natural Earth data (2016) Admin - Countries, version 3.1.0. http:// www.naturalearthdata.com/downloads/10m-cultural-vectors/ (Accessed 13/10/2016).

NordGen (2016) NordGen forage lists: A list of species classified as forages at NordGen and the current list of prioritised forage species from the forage working group at NordGen.

Parra-Quijano M (2016) CAPFITOGEN Tools, Program to Strengthen Capabilities in National Plant Genetic Resources Programs in Latin America, Version 2.0. International Treaty on Plant Genetic Resources for Food and Agriculture, FAO. http://www.capfitogen.net/en/ (Accessed 10/09/2016).

Parra-Quijano M, Iriondo JM and Torres ME (2012) Ecogeographical land characterization maps as a tool for assessing plant adaptation and their implications in agrobiodiversity studies. Genetic Resources and Crop Evolution 59: 205-217.

Parra-Quijano M, Torres E, Iriondo JM and López F (2014) CAPFITOGEN Tools User Manual Version 1.2. Rome, Italy: International Treaty on Plant Genetic Resources for Food and Agriculture, FAO, 138p. ISBN 978-92-5-108493-9

Phillips J, Asdal $\AA$, Magos Brehm J, Rasmussen M and Maxted N (2016) in situ and ex situ diversity analysis of priority crop wild relatives in Norway. Diversity and Distributions 22: $1112-1126$.

Rebelo AG (1994) Iterative selection procedures: centres of endemism and optimal placement of reserves. In: Huntley BJ (ed.) Botanical Diversity in Southern Africa. Pretoria: National Botanical Institute, pp. 231-257.

Reuter HI, Nelson A and Jarvis A (2007) An evaluation of void filling interpolation methods for SRTM data. International Journal of Geographic Information Science 21: 983-1008.

Rosenzweig C and Parry ML (1994) Potential impact of climate change on world food supply. Nature 367: 133-138.

USDA (2016) World Economic Plants in GRIN. Online Database, GrinGlobal version 1.9.9.2 https://npgsweb.ars-grin.gov/ gringlobal/taxon/taxonomysearcheco.aspx (Accessed 10/ 3/2016).

Vincent H, Wiersema J, Dobbie S, Kell S, Fielder H, Castaneda N, Guarino L, Eastwood R, Leon B and Maxted N (2013) A prioritized crop wild relative inventory to help underpin global food security. Biological Conservation 167: 265-275.

Worldclim (2016) Worldclim - Global Climate Data. Version 1.4. Berkeley: Museum of Vertebrate Zoology, University of California. http://www.worldclim.org (Accessed 10/9/2016).

Whittaker RJ and Fernandez-Palacios JM (2007) Island Biogeography: Ecology, Evolution, and Conservation. 2nd edn. New York: Oxford University Press.

UNEP-WCMC and IUCN (2016) Protected Planet, the World Database on Protected Areas. Cambridge, UK: United Nations Environment World Conservation Monitoring Centre (UNEP-WCMC) and IUCN. Available at: www.protectedplanet. net (Accessed 30/11/2016). 